Studia z Dziejów Średniowiecza, t. 23, 2019

\author{
Andrzej Marzec \\ (Instytut Historii, Uniwersytet Jagielloński)
}

\title{
Dokument królowej Elżbiety Łokietkówny z 1 stycznia 1377 roku, w potwierdzeniu wikariuszy Królestwa Polskiego z 26 czerwca 1381 roku
}

https://doi.org/10.26881/sds.2019.23.17

Keywords: medieval privileges, Queen Elisabeth of Hungary (the Older), King Louis the Great of Hungary

W dniu 1 stycznia 1377 r. królowa Elżbieta Łokietkówna wystawiła w Krakowie dokument, którego odbiorcą był biskup Seretu Andrzej, kapelan królowej. W dyplomie tym monarchini zwalniała tegoż Andrzeja, plebana w Kłodawie, z czynszów należnych skarbowi królewskiemu z części majątku przynależnego do plebanii kłodawskiej. Dokument jest jednym z kilku źródeł poświadczających pobyt Elżbiety w Krakowie na przełomie lat 1376/1377.

Późnym latem 1376 r. do Królestwa Polskiego przybyła Elżbieta Łokietkówna, starsza królowa Węgier i Polski. Przybyła, aby po raz drugi objacc w imieniu swego syna Ludwika rządy namiestnicze w Krakowie $^{1}$. Monarchini nie zdawała sobie sprawy, jak poważne i niebezpieczne zdarzenia będą związane z jej powrotem do Polski. Przyjechała jednak bez watpienia $\mathrm{z}$ wielkim przepychem i splendorem, wysyłając wcześniej listy, w których zażądała od szlachty krakowsko-sandomierskiej, aby ta wraz z rodzinami przybyła do Nowego Sącza i, witajac królowa, towarzyszyła jej aż do Krakowa. Już w drodze na Wawel doszły Elżbietę wieści, że Litwini planują napad na ziemię

1 Joannis de Czarnkow Chronicon Polonorum, wyd. J. Szlachtowski, MPH, t. 2, Lwów 1872, s. 674-675; J. Dąbrowski, Elżbieta Eokietkówna 1305-1380, Kraków 1914 (reedycja Kraków 2007), s. 144-151. 
sandomierska, ale miała się tym szczególnie nie przejąć. Uważała, że potęga jej syna jest niezachwiana, a ewentualni najeźdźcy poniosa z jego ręki słuszna karę ${ }^{2}$. Litwini jednak wtargnęli do ziemi sandomierskiej i dotarli aż w okolice Tarnowa, dokonując dość poważnych zniszczeń, rabunków i porwań ludzi ${ }^{3}$. Królowa, będąc w Krakowie, niewiele mogła uczynić, ale jak się okazało, najgorsze miało ją jeszcze czekać. Jej powrót do Królestwa Polskiego został opisany przez kronikarza jako jej swego rodzaju fanaberię. W końcu roku 1375 Elżbieta prawdopodobnie opuściła Kraków z zamiarem niewracania do Polski, ponieważ jej namiestnicze rządy miały ucierpieć z powodu nieodpowiedzialnej polityki otaczających ją dostojników. Jan z Czarnkowa, będący w zasadzie głównym źródłem informacji na temat dziejów andegaweńskiego panowania w Polsce, nie szczędząc złośliwości, napisał, że Elżbieta, zniechęcona sytuacją w Polsce, wróciła na Węgry i dostała od syna w zarząd Dalmację wraz z bardzo wysokimi dochodami. Kronikarz jednak nie podał żadnych konkretów, co zmusiło królową do opuszczenia Królestwa Polskiego ${ }^{4}$. Również nie wiadomo, dlaczego nagle zażądała od swego syna Ludwika, aby wysłał ją z powrotem do Polski, mimo że, jak napisał Jan z Czarnkowa, miał inne plany ${ }^{5}$. Opis kronikarza, nacechowany przede wszystkim niechęcią do Elżbiety, nie pomaga w wyjaśnieniu przyczyn tej sekwencji zdarzeń i motywacji kierujących zarówno królową Elżbieta, jak i jej synem Ludwikiem.

Można tylko domniemywać, że królowa wdowa wróciła do Krakowa, bo Ludwik nie był jednak w stanie, po jej wyjeździe w połowie 1375 r., zorganizować w czasie swoich notorycznych nieobecności wystarczająco sprawnego mechanizmu zarządzania Królestwem Polskim. Niedługo po wyjeździe Elżbiety druga próbę zdobycia władzy nad Kujawami podjął książę Władysław Biały. Walki z nim, kierowane przez starostów, przeciagnęły się aż do $1376 \mathrm{r} .{ }^{6} \mathrm{~W}$ początkach tego roku do Krakowa na krótko przyjechał król Ludwik, zapewne

2 Joannis de Czarnkow Chronicon..., s. 674.

3 Wymowny opis tych zdarzeń, wraz z przytoczeniem mrożących krew w żyłach epizodów, podał Jan z Czarnkowa - Joannis de Czarnkow Chronicon..., s. 675.

4 Ibidem, s. 674: „Anno itaque eodem Elisabeth, mater domini Lodvici regis Ungarie, quae anno praecedenti regnum Poloniae gubernandum filio suo regi Ungariae praedicto dimiseret, propter disturbia, quae in eodem sedule fiebant gubernantibus et regentionibus, quibusdam nobilibus Cracoviensibus, qui ipsam reginam ad multa instabilia suis pravis consiilis deducebant".

5 Ibidem.

6 Czołową rolę w walkach z księciem Władysławem odgrywali starosta wielkopolski Sędziwój z Szubina oraz starostowie brzescy Bartosz z Wezenborga i Bartosz 
w celu osobistego dopilnowania przygotowań do rozprawy z kujawskim Piastem ${ }^{7}$. Tak więc przybycie Elżbiety do Polski w początkach października 1376 r. nie było chyba tylko i wyłącznie jej zachcianka, którą dla świętego spokoju postanowił spełnić jej syn Ludwik. Krótki stosunkowo pobyt królowej w Krakowie na przełomie 1376 i 1377 r. jest kojarzony przede wszystkim z tragicznymi wydarzeniami, jakie miały miejsce w grudniu i skończyły się pogromem Węgrów, podczas którego miało ich zginać nawet stu sześćdziesięciu ${ }^{8}$. I niewątpliwie było to wydarzenie znaczace o bardzo silnym oddźwięku, ale w czasie pobytu królowej w Polsce doszło nie tylko do rozruchów w mieście Krakowie. Jedna z kluczowych decyzji, która podjęła monarchini, bez wątpienia w imieniu swego syna Ludwika, była roszada personalna na kluczowych urzędach starościńskich. Zmiany nastapiły w Krakowie, Wielkopolsce i na Kujawach. Starostwo generalne wielkopolskie odebrano Sędziwojowi z Szubina i powierzono Domaratowi z Pierzchna i Iwna, Sędziwój zaś został mianowany starosta krakowskim. Na Kujawach starostami przestali być Bartosz z Wezenborga i Bartosz z Sokołowa, ich urząd przeszedł w ręce Piotra Małochy h. Grzymała ${ }^{9}$. Zmiany na urzędach w świetle przekazu Jana z Czarnkowa dokonały się w wyniku rzezi krakowskiej i zabicia dotychczasowego starosty krakowskiego Jana Kmity z Wiśnicza, którego zgon utorował drogę do awansu Sędziwojowi. Mianowanie zaś jego następcy w Wielkopolsce miało być nagroda dla Domarata za ratowanie mordowanych w Krakowie Węgrów ${ }^{10}$. Wydarzenia krakowskie były niewątpliwie pretekstem pozwalającym królowej przeprowadzić roszadę na najważniejszych urzędach królestwa. Jednak fakt odwołania także starostów kujawskich, którzy przecież sprawnie i z oddaniem wojowali z księciem Władysławem Białym, każe spojrzeć na decyzje Elżbiety jako coś bardziej skomplikowanego niż wyłącznie reakcja na zabicie krakowskiego starosty. Tomasz Nowakowski i Janusz Kurtyka doszukiwali się w tym odwiecznej walki stronnictw politycznych, dzielących elity królestwa jeszcze od czasów Kazimierza

\footnotetext{
z Sokołowa - R. Bubczyk, Kariera rodziny Kurozwęckich w XIV wieku. Studium z dziejów powiazań polskiej elity politycznej z Andegawenami, Warszawa 2002, s. 115-122.

Ibidem, s. 119-120.

Joannis de Czarnkow Chronicon..., s. 675-676.

UM, s. 286; UW, nr 611; UKD, s. 133, 134.

10 A. Marzec, Pod rzqdami nieobecnego monarchy. Królestwo Polskie 1370-1382, Kraków 2017, s. 137-148.
} 
Wielkiego ${ }^{11}$. Warto jednak spróbować odpowiedzieć na pytanie, jaki był kontekst tych zmian, przyglądając się przede wszystkim źródłom i to źródłom współczesnym decyzjom monarszym.

Przybycie królowej Elżbiety do Krakowa w jesieni 1376 r. na pewno nie było spowodowane zagrożeniem litewskim czy też narastającymi antagonizmami polsko-węgierskimi. Można zaryzykować twierdzenie, że jej przyjazd był podyktowany koniecznością rozstrzygnięcia spraw w królestwie, nagromadzonych w toku jej rocznej nieobecności i zapewne ściśle związanych z wojną z księciem Władysławem Białym ${ }^{12}$. Prócz spraw najważniejszych, czy też może tych związanych ze szczytami krajowej polityki, królowa miała załatwić sprawy wagi mniejszej, ale także wymagające królewskiego majestatu. W okresie bezpośrednio poprzedzającym opisywany pobyt Elżbiety w Królestwie Polskim nastąpiły istotne zdarzenia na Rusi, gdzie, z inicjatywy króla Ludwika, doszło do trwałego powstania tamtejszej organizacji kościelnej opartej na arcybiskupstwie halickim. W sprawy te od lat panowania Kazimierza Wielkiego był zaangażowany Andrzej ze Skroniowa i Zabłocia h. Jastrzębiec,

11 J. Kurtyka, Tęczyńscy. Studium z dziejów elity możnowładczej w średniowieczu, Kraków 1997, s. 195; T. Nowakowski, Polityka pótnocna Polski w latach 1356-1364 na tle jej sytuacji wewnętrznej, „Akademia Techniczno-Rolnicza w Bydgoszczy. Zeszyty Naukowe. Nauki Społeczne" 1980, t. 72, nr 10, s. 79.

12 Najbardziej spektakularną decyzją było usunięcie ze starostwa kujawskiego Bartoszów z Wezenborga i Sokołowa, którzy, szczególnie Bartosz z Wezenborga, odegrali kluczową rolę w pokonaniu Władysława Białego. W świetle relacji Jana z Czarnkowa to właśnie Bartosz był tym, który ostatecznie, w pojedynku, pokonał księcia, raniąc go w prawy bark i na swój koszt wyekspediował go na dwór królewski do Budy - Joannis de Czarnkow Chronicon..., s. 660. Trudno wyjaśnić bezpośrednią przyczynę tych decyzji królewskich, ale nie można wykluczyć, że w trakcie walk z księciem kujawskim doszło do konfliktu w łonie dostojników stających na czele wojsk królewskich. Mogło też dojść do zmiany instrukcji monarszych w toku walk z Władysławem, czego efektem było wynegocjowane porozumienie. Król mógł żądać całkowitego rozprawienia się z wichrzycielem, a nie zawierania z nim kompromisu. Tymczasem wiadomo, że ustalono rozejm, książę miał oddać zamek w ręce Bartosza z Wezenborga, a potem ruszyć do króla w celu zawarcia porozumienia. W przypadku niepowodzenia rozmów z monarchą Złotoria miała wrócić w ręce księcia - Franciscani Thorunesis Annales Prussici, hrsg. v. M. Töppen, T. Hirsch, SRP, Bd. 3, Lepzig 1866, s. 103; R. Bubczyk, Kariera rodziny..., s. 121. Być może Bartosz i jego siostrzeniec zostali kozłami ofiarnymi, na których wyładował się królewski gniew za zbyt łaskawe potraktowanie Władysława Białego. Doszły do tego pewnie intrygi Domarata, chętnego do objęcia kujawskiego starostwa i gotowego na pomniejszenie swych dochodów z tego urzędu. Warto pamiętać o królewskim gniewie niedługo potem, kiedy możni polscy nie chcieli rozprawić się ze zbuntowanym Bartoszem z Wezenborga, tylko prowadzili z nim negocjacje, co król odebrał jako uwłaczające jego godności - Joannis de Czarnkow Chronicon..., s. 698-699. 
franciszkanin, spowiednik Kazimierza Wielkiego, kapelan na dworze Elżbiety Łokietkówny ${ }^{13}$. Niedługo przed śmiercią Kazimierza Wielkiego, w lecie 1370 r., został biskupem w mołdawskim Serecie, a w styczniu 1372 r. - decyzją Grzegorza XI - biskupem przemyskim ${ }^{14}$. Funkcję tę sprawował do początków 1376 r., kiedy w wyniku papieskich decyzji została oficjalnie zorganizowana archidiecezja halicka, na której czele stanał świecki duchowny Maciej. Andrzej zakończył swą misję na wschodzie $^{15}$ i, tytułując się nadal biskupem Seretu, został biskupem pomocniczym przy arcybiskupie gnieźnieńskim Januszu Suchymwilku. Wtedy też otrzymał, zapewne za staraniem króla i królowej, plebanię w Kłodawie, której dotychczasowy dzierżyciel umarł ${ }^{16}$. Otrzymanie kościoła kłodawskiego było bez wątpienia wynagrodzeniem i zabezpieczeniem materialnym dla zasłużonego duchownego, który od wielu lat angażował się w politykę kościelną króla polskiego i węgierskiego na wschodnich rubieżach ich władztw. W dniu 1 stycznia 1377 r. kancelaria królewska w Krakowie wygotowała pergamin, który informował Andrzeja, że królowa Elżbieta zrezygnowała na jego korzyść z przysługującego jej czynszu w wysokości jednego wiardunku groszy, który płacił do tej pory pleban kłodawski Jan z łanu zwanego Rozniatowski oraz z czynszu w wysokości jednego grosza, płaconego z ogrodu. Ponadto oddawała rzeczony łan z ogrodem na wieczną własność kościoła i plebana kłodawskiego, zwalniajac jego właścicieli z wszystkich możliwych zobowiązań na rzecz monarchy. Wszystko zaś uczyniła za zbawienie duszy swojej, swego syna Ludwika i swego ukochanego brata Kazimierza.

Omawiany dokument był jednym z ostatnich, który Elżbieta wystawiła podczas owego pobytu w Królestwie Polskim. Ostatni dyplom poświadczający pobyt monarchini z Krakowie pochodzi z dnia 9 stycznia 1377 r. ${ }^{17}$ Pod względem dyplomatycznym dokument królowej nie różni się od tych wystawianych przez nią i przez Ludwika, które, jeżeli były redagowane w polskiej kancelarii królewskiej, zachowywały

13 B. Czwojdrak, Jastrzębce $w$ ziemi krakowskiej $i$ sandomierskiej do połowy XV wieku, Kraków 2007, s. 37-38.

14 W. Abraham, Powstanie i poczatki Kościoła łacińskiego na Rusi, Lwów 1904, s. 285-286, 292; idem, Biskupi łacinscy w Mołdawii w XIV i XV wieku, KH, 1902, t. 16, s. $180-1982$.

15 W. Abraham, Powstanie i poczatki..., s. 302.

16 Jego rolę jako sufragana gnieźnieńskiego potwierdza m.in. Jan z Czarnkowa, wspominając Andrzeja jako negocjującego z księciem Siemowitem IV w sprawie dóbr łowickich zajętych przez księcia mazowieckiego na wieść o zgonie Suchegowilka - Joannis de Czarnkow Chronicon..., s. 715-716.

17 KKK, t. 2, nr 296. 
formularz wypracowany za panowania Kazimierza Wielkiego. Podobnie rzecz się ma z potwierdzeniem z roku 1381, które zostało również spisane według tego formularza, tak jak były redagowane inne dokumenty wystawiane przez wikariuszy królestwa w imieniu Ludwika. Dokumentu dla Andrzeja z Zabłocia dotychczas nie wydano drukiem, choć był znany historiografii ${ }^{18}$. Brak edycji odbił się jednak na znajomości tego dyplomu w niektórych pracach, również takich, w których jego wykorzystanie miałoby istotne znaczenie. Przykładem może być monografia poświęcona rodowi Nałęczów w średniowiecznej Wielkopolsce pióra Jana Pakulskiego ${ }^{19}$. Autor, rysując sylwetkę Jana z Czarnkowa, podczaszego i sędziego poznańskiego, napisał, że nie wiadomo, kiedy ów Jan objął urząd sędziowski, ponieważ jego poprzednik Przecław z Prusinowa znika ze źródeł po 26 czerwca 1375 r., Jan zaś na urzędzie pojawia się po raz pierwszy 25 kwietnia $1377 \mathrm{rr}^{20}$ Tymczasem w dyplomie Elżbiety Łokietkówny dla Andrzeja z Zabłocia z 1 stycznia 1377 r. w liście świadków występuje Jan Czarnkowski bez żadnego urzędu ${ }^{21}$. Można zatem przyjąć, że objęcie przez niego urzędu sędziego poznańskiego było bezpośrednim następstwem królewskiej wizyty w Krakowie. Tak więc Jan h. Nałęcz zostałby sędzią między 1 stycznia a 25 kwietnia 1377 r. To też pokazuje, że wizyta królowej w Polsce nie była związana wyłącznie ze zmianami na najważniejszych urzędach starościńskich, ale dotyczyła wielu innych nieco mniej spektakularnych dostojeństw i, jak można domniemywać, pojawienie się Elżbiety po rocznej nieobecności ściagnęło do Krakowa liczne grono osób mających sprawy do królewskiego majestatu.

Zachowany dyplom królowej Węgier i Polski kryje w sobie jeszcze jedną wartość - formę. Został bowiem wpisany do Metryki Koronnej dokładnie w takiej formie, w jakiej dostarczono go kancelarii - był

18 I. Sułkowska-Kurasiowa, Dokumenty królewskie $i$ ich funkcja w państwie polskim za Andegawenów i pierwszych Jagiellonów 1370-1444, Warszawa 1977, s. 23; R. Bubczyk, Kariera rodziny..., s. 124, ale z błędną identyfikacją odbiorcy dokumentu. Autor uznał, że odbiorcą był klasztor augustianów w Kłodawie.

19 J. Pakulski, Nałęcze wielkopolscy w średniowieczu. Genealogia, uposażenie $i$ rola polityczna $w$ XII-XIV $w$., Toruń 1982.

20 Ibidem, s. 65-66.

21 W ostatniej mojej książce (A. Marzec, Pod rzadami..., s. 140) snułem nieśmiałe rozważania, czy tym Janem nie był być może kronikarz Jan z Czarnkowa, archidiakon gnieźnieński, ale skłaniam się ku temu, również kiedy pisałem książkę, że chodziło o Nałęcza Jana z Czarnkowa, który niedługo po spotkaniu z królową objął sędstwo poznańskie i zapewne staraniom o ten urząd była podporządkowana jego wizyta w Krakowie. 
potwierdzeniem decyzji królowej uczynionym w imieniu jej syna Ludwika, króla Polski, przez reprezentujących go na obszarze królestwa wikariuszy zwanych też wielkorządcami Królestwa Polskiego. Krótka historia owego eksperymentu ustrojowego, polegającego na wyznaczeniu przez Ludwika kolegialnego ciała majacego załatwiać w jego imieniu wszystkie istotne sprawy królestwa, była już szeroko omawiana w literaturze ${ }^{22}$. Warto jednak zwrócić uwagę na jedną kwestię - datę dokumentu wikariuszy potwierdzającego nadanie Elżbiety, brzmi ona: „Actum in Brzesczie quarta feria proxima post diem sancti Ioannis Baptistae, anno domini millesimo trecentesimo octuagesimo primo”. Irena Sułkowska-Kurasiowa przyjęła, nie wiadomo dlaczego, że dokument został spisany przez wielkorządców w podpoznańskiej wsi Brzeście i być może to skłoniło Roberta Bubczyka do takiej samej interpretacji nazwy tej miejscowości ${ }^{23}$. Tymczasem zapisana w dyplomie data to dzień środa po dniu świętego Jana Chrzciciela, które to święto przypada na dzień 24 czerwca. Według bardzo wiarygodnego przekazu Jana z Czarnkowa wikariusze królestwa rozpoczęli objazd Kujaw i Wielkopolski właśnie od wiecu w Brześciu Kujawskim, zwołanym nazajutrz po św. Janie: „Jusserunt in crastino sancti Johannis Baptistae in terminis generalibus in Brzescze proclamari" "24. Tak więc dokument wikariuszy, zawierajacy nadanie królowej Elżbiety, potwierdza i umacnia kronikarski przekaz archidiakona gnieźnieńskiego.

Omawiany w artykule dokument, a właściwie dokumenty zachowały się w trzech przekazach. Pierwszy i chyba najstarszy to wpis do Metryki Koronnej, księgi 91 z lat 1557-1559. Został dokonany na wniosek prepozyta konwentu augustianów w Kłodawie i wpisany w dniu 25 września $1558 \mathrm{r} .{ }^{25}$ Ten sam dokładnie wpis został powtórzony w skopiowanych fragmentach z księgi 91 Metryki, które znajdują się w księdze $92^{26}$. Trzecia kopia pochodzi z Archiwum Publicznego Potockich z drugiej połowy wieku XVIII ${ }^{27}$. Dokument znalazł się tam zapewne dlatego, że wpadł w ręce Stanisława Kostki Potockiego,

22 J. Dąbrowski, Ostatnie lata Ludwika Wielkiego 1370-1382, Kraków 1918 (reedycja Kraków 2009), s. 326-341; A. Marzec, Pod rzqdami..., s. 159-174.

23 I. Sułkowska-Kurasiowa, Dokumenty królewskie..., s. 21; R. Bubczyk, Kariera rodziny..., s. 146 .

24 Joannis de Czarnkow Chronicon..., s. 697.

25 AGAD, Metryka Koronna, ks. 91, k. 384v-387.

26 Ibidem, ks. 92, k. 676v-679v.

27 AGAD, Archiwum Publiczne Potockich, sygn. 304, s. 485-489. 
gromadzącego różne publiczne dokumenty ${ }^{28}$. W zbiorze Potockich znalazła się kopia potwierdzenia Zygmunta Augusta z roku 1558, ale warto zauważyć, że osiemnastowieczny kopista dobrze przepisał imiona dwóch urzędników wymienianych w dokumentach. Chodzi o imię „Dobeslaus”, które pisarz kancelarii królewskiej w wieku XVI błędnie odczytał jako „Boleslaus”. Prócz tego istnieje jeszcze kilka odmian lekcji poszczególnych słów, a nawet zwrotów. Właśnie te różnice, pomiędzy kopią pochodząca z Metryki a wpisem w Archiwum Potockich, pozwalają na wysunięcie hipotezy, że dokumenty trafiły tam nie poprzez Metrykę, ale wprost z oryginału Zygmunta Augusta, w którym lekcje imion mogły być poprawne (także Jana Czarnkowskiego, który w Metryce został określony jako Jan Czarnowski, w archiwum Potockich zaś jako Jan Czarnkowski).

\section{Aneks źródłowy}

Brześć Kujawski, 26 czerwca 1381

Ludwik król Polski (wikariusze królestwa) potwierdza dyplom królowej Elżbiety Eokietkówny z 1 I 1377 r., która zwalnia z czynszów tan zwany Rozniatowski i ogród, należace do plebana $w$ Kłodawie Andrzeja, biskupa Seretu, kapelana królowej i spowiednika Kazimierza Wielkiego. Jednocześnie nadaje wieczyście ów tan i ogród plebanowi kłodawskiemu. Czyni to wszystko za zbawienie duszy swojej, swego syna Ludwika króla Polski i nieżyjacego brata Kazimierza.

Oryg.: Brak.

Kop.: 1. AGAD, Metryka Koronna, ks. 91, k. 383v.-387r. (potwierdzenie króla Zygmunta Augusta na wniosek prepozyta konwentu augustianów $w$ Kłodawie, $z 25$ września 1558 roku, na podstawie oryginatu); 2. AGAD, Metryka Koronna, ks. 92 (kopie wpisów do MK, ks. 91), k. 676v-679v; 3. AGAD, Archiwum Publiczne Potockich, sygn. 304, s. 485-489 (na podstawie oryginatu).

Reg.: MRPS, t. 5/2, $\mathrm{nr} 8435$.

28 Archiwum Główne Akt Dawnych w Warszawie. Informator o zasobie archiwalnym, red. D. Lewandowska, Warszawa 2008, s. 570. 
Uw.: Tekst źródta wydany wedtug zasad zawartych $w$ A. Wolff, Projekt instrukcji wydawniczej dla pisanych źródeł historycznych do połowy XVI wieku, SŹ, t. 1, 1957.

In nomine domini amen. Plenitudo fiduciae in humanis actibus ${ }^{a}$, tunc concernitur quando labenti, memoriae scriptis litteris authenticis veridice subuenitur ${ }^{b}$. Eapropter nos Ludovicus Dei gratia rex Ungariae, Poloniae, Dalmatiae, Croatiae etc. ad universorum et singulorum, tam praesentium quam futurorum noticiam volumus, devenire, quod oblata nobis pro parte reverendi in Christo patris domini Andreae episcopi Ceretenensis ${ }^{1}$, nostri devoti ac fidelis peticio continebat, quatenus sibi literam sanctae et aeternae memoriae serenissimae principis dominae Elisabeth eadem gratia reginae regnorum praedictorum, nostrae genitricis charissimae. Sanam et integram, omnique ${ }^{c}$ suspicione prorsus et vicio carentis, eiusque sigillo maiori appenso sigillatam, confirmare, ratificando de immata nobis clementia, dignaremur. Cuiusquidem litterae tenor per omnia sequitur in hac verba.

In nomine domini amen. Quia dignum est, ut ea quae geruntur in tempore, ne simul cum tempore evanescant ${ }^{d}$, literarum apicibus cum annotacione $^{e}$ testium debeant, prout sapiensum sanxerit, authoritas posterorum noticiae commendari, hinc est, quod nos Elizabet Dei gratia senior regina Vungariae et Poloniae ad universorum noticiam, tam praesentium, quam futurorum, volumus devenire, quod cum reverendus in Christo pater dominus Andreas episcopus Ceretenesis, capellanus noster in Christo devotus confessorque quondam illustrissimi principis domini Cazimiri regis Poloniae, fratris nostri charissimi, tunc rector ecclesiae Klodawiensis ${ }^{2}$ existens, pro quosdam manso, qui dicitur wulgari nomine Rozniathowski, de quo dominus Ioannes ${ }^{3}$, rector ecclesiae Klodawiensis, nostris antecessoribus et nobis, annis singulis, fertonem persolvebat, et horto penes hortum, eiusdem ecclesiae Clodawiensis adiacente, de quo grossus solvebatur, nobis humiliter supplicasset, ut sibi et suae ecclesiae Clodawiensis mansum memoratum et hortum penes hortum dictae ecclesiae adiacentem, ob remedium nostrae et nostri filii charissimi domini Ludovici salutem et refrigerium animae illustrissimi principis domini Cazimiri, fratris nostri, pie recordationis, regis Poloniae illustris, ad honorem sancti Egidii, gloriosi confessoris prefatae ecclesiae Clodawiensis patroni et ad ipsam ecclesiam dare, et assignare perpetuo misericorditer dignaremur. Nos vero suis peticionibus pie et benigne annuentes, praefatum mansum et hortum, sibi et suae ecclesiae praedictae, ac suis succesoribus, ob remedium nostrae et nostri 
filii charissimi Ludovici salutem, et refigerium animae illustrissimi principis domini Cazimiri praefati $f$, assignamus, contulimus et dedimus, ac etiam assignamus, conferimus, damus et donamus eternis singulis perpetue duraturis, faciens ipsos mansum ${ }^{g}$ et hortum, ob omnibus solutionibus, expedicionibus, exactionibus, laboribus, et angariis universis, quibuscunquae nominibus censeantur, liberos, et solutos. Tali tamen condicione interclusa quod rector ecclesiae nominatae, et quilibet successor ipsius, qui pro tempore fuerit, pro anima domini ${ }^{h}$ Cazimiri, fratris nostri memorati, anniversarium facere debeant, quod singulis annis simul in anno vigilias novem lectionum, et voce missam defunctorum decantabit. In cuius rei testimonium nostrum sigillum praesentibus est appensum. Datum et actum Cracoviae, die circumcisonis Domini, per manus honorablilis viri domini Zavissi cancellarii nostri Cracoviensis ${ }^{4}$, sub anno domini millesimo trecentesimo septuagesimo septimo. Praesentibus iis ${ }^{i}$ strenuis et nobilibus viris Creslao castellano Sandecensi ${ }^{5}$, Andrea subiudice Cracoviensi ${ }^{6}$, Jancone Czarnowskij ${ }^{7}$, Navogio herede $\mathrm{de}^{i}$ Siedlissewicze $^{8}$, Zawissio castellano Brzezniensi ${ }^{9}$, Michalcone ${ }^{10}$ et Nicolao ${ }^{11}$ canonicis Cracoviensis, ac aliis quamplurimis fidedignis.

Nos igitur praefati Andreae episcopi peticionibus gratiosis ${ }^{k}$ aclinati supradictam litteram in omnibus suis punctis, articulis, sentenciis et clausulis ratam, gratam atque firmam habentes, ratificamus, gratificamus, aprobamus, et virtute praesentium confirmamus. Volentes et decernentes dictam litteram, in praefatus suis articulis, clausulis, punctis ac sentenciis robur obtinere, perpatuae firmitatis. Harum quibus sigillum nostrum est appensum, testimonio litterarum. Actum in Brzesczie ${ }^{12}$ quarta feria proxima post diem sancti Ioannis Baptistae, anno domini millesimo trecentesimo octuagesimo primo. Praesentibus magnificis et nobilibus viris Dobeslao ${ }^{l}$ castellano $^{13}$, Sandivogio capitaneo Cracoviensibus ${ }^{14}$, Boleslao ${ }^{1}$ Crusvicensi ${ }^{15}$, Oswaldo Wladislaviensi ${ }^{16}$, Cristino Cowaliensi castellanis ${ }^{17}$ ac aliis multis fidelibus nostris fidedignis. Datum per manus Ioannis Radlicze, cancellarii supremi regni Poloniae ${ }^{18}$ nostri praedicti.

\footnotetext{
a Kop. 3: actionibus.

b Kop. 3: subventis.

Kop. 3: omniumque.

d Kop. 1: coanescant.

e Kop. 3: connotatione.

${ }^{f}$ Kop. 3: praedicti.

${ }^{g}$ Kop. 3: mansos.
} 
h Kop. 3: brak.

i Kop. 3: hiis.

j Kop. 3: Czarnkowski.

k Kop. 3: gratiosius.

1 Kop. 3: Dobeslao.

1 Andrzej z Zabłocia h. Jastrzębiec, syn Andrzeja, brat Niemsty ze Skroniowa i Mikołaja kanonika krakowskiego, bp Seretu (1370), Halicza (1372) i sufragan archidiecezji gnieźnieńskiej (1377-1392), biskup wileński (1388), pleban w Kłodawie - W. Abraham, Biskupi tacińscy w Mołdawii, KH 1902, t. 16, s. 180-182; B. Czwojdrak, Jastrzębce..., s. 36-37.

2 Kłodawa, miasto w dawnej ziemi łęczyckiej, około 50 km na wschód od Konina.

3 Jan, pleban w Kłodawie, bliżej nieznany.

4 Kurozwęki, wieś w dawnej ziemi sandomierskiej, około 7 km na północny zachód od Staszowa. Zawisza h. Poraj, syn Dobiesława wojewody i kasztelana krakowskiego, brat Krzesława kasztelana sądeckiego, podkanclerzy dworu i kanclerz krakowski w latach 1370-1382 - R. Bubczyk, Kariera rodziny..., według indeksu.

5 Krzesław z Kurozwęk, syn Dobiesława wojewody i kasztelana krakowskiego, brat Zawiszy, kasztelan sądecki - ibidem, według indeksu.

6 Wawrowice, wieś w dawnej ziemi sandomierskiej, około $5 \mathrm{~km}$ na południe od Wiślicy. Andrzej h. Sulima, podsędek krakowski - UM, s. 101.

7 Jan Czarnkowski, zapewne tożsamy z sędzią ziemskim poznańskim Janem z Czarnkowa h. Nałęcz, po raz pierwszy notowanym na urzędzie w kwietniu $1377 \mathrm{r}$. (KDW 3, 1736) - J. Pakulski, Nałęcze..., według indeksu.

8 Siedliszowice, wieś w dawnej ziemi sandomierskiej, około $6,5 \mathrm{~km}$ na południe od Opatowca. Nawój, nie ma pewności, czy tożsamy z Nawojem z tych samych Siedliszowic, zm. około 1420-1422, którego żoną była Anna, a synem Mściwoj z Wietrzychowic (także w powiecie wiślickim), dorosły już z całą pewnością w $1421 \mathrm{r}$. (SHGK, cz. 2, s. 118 ; cz. 3, s. 53, 902).

9 Zawisza, kasztelan brzeziński - UŁS, s. 35.

10 Michałko, kanonik krakowski, zapewne identyczny z Michałkiem (zw. Niedźwiedź), kanonikiem krakowskim znanym w latach 1367-1373-M.D. Kowalski, Prałaci i kanonicy krakowskiej kapituty katedralnej od pontyfikatu biskupa Nankera do śmierci biskupa Zawiszy z Kurozwęk (1320-1382), Kraków 1996, s. 209.

11 Mikołaj, kanonik krakowski, być może tożsamy z Mikołajem synem Andrzeja ze Skroniowa h. Jastrzębiec, bratem biskupa Andrzeja, odbiorcy niniejszego dokumentu - M.D. Kowalski, Prałaci i kanonicy..., s. 224.

12 Brześć Kujawski, dawna stolica województwa brzeskiego, około 13 km na zachód od Włocławka.

13 Dobiesław z Kurozwęk h. Poraj, wojewoda i kasztelan krakowski - R. Bubczyk, Kariera rodziny..., według indeksu.

14 Szubin, wieś około $24 \mathrm{~km}$ na południowy zachód od Bydgoszczy, Sędziwój h. Pałuka (Topór), starosta wielkopolski i starosta krakowski-A. Gąsiorowski, Sędziwój z Szubina, PSB, t. 36, Warszawa-Kraków 1995-1996, s. 406-416.

15 Dobiesław z Kościoła h. Ogon, kasztelan kruszwicki - UKD, s. 116.

16 Oswald z Płomykowa h. Pomian, kasztelan inowrocławski - UKD, s. 95.

17 Krystyn (Krzczon) ze Świętego h. Łabędź, kasztelan kowalski - UKD, s. 112.

18 Jan zw. Radlica z Radliczyc h. Korab, kanclerz Królestwa Polskiego, biskup krakowski - UC, s. 52. 


\begin{abstract}
A document of Elisabeth of Poland, Queen of Hungary, of the $1^{\text {st }}$ of January 1377 , in the validation of the vicars of the Kingdom of Poland of the $16^{\text {th }}$ of April 1381
\end{abstract}

This paper contains the never-before-published document of Elisabeth of Poland, Queen of Hungary, of the $1^{\text {st }}$ January 1377, drawn up in Cracow and later validated by the vicars of the Kingdom of Poland on the $16^{\text {th }}$ April 1381. The addressee of the document was the bishop of Seret Andrzej, chaplain of the queen and a parson in Kłodawa. In this diploma, the queen exempted him from paying rent to the royal treasury from some of the land belonging to the Kłodawa parish. The document is one of several sources confirming Elisabeth's stay in Cracow in 1376/1377. 